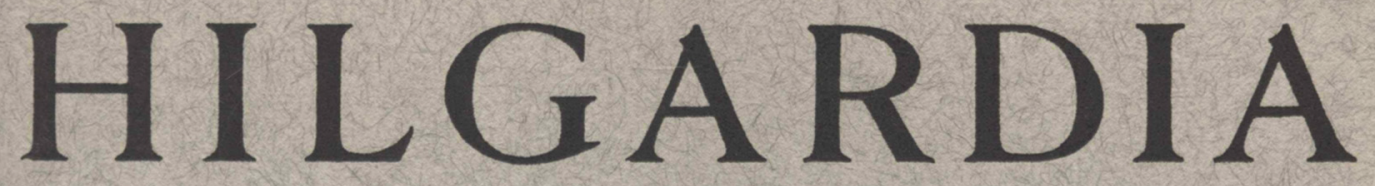

A Journal of Agricultural Science Publisbed by the California Agricultural Experiment Station

\title{
INHERITANCE OF FOUR MORPHOLOGICAL CHARACTERS IN LIMA BEANS
}

\author{
R. W. ALLARD
}


Four gene pairs governing the inheritance of conspicuous morphological characters in lima beans are described. They are:

Dd-indeterminate (vine) vs. determinate (bush) habit of growth.

Vv-variegated vs. nonvariegated leaflets.

WIwl-lanceolate vs. ovate leaflets; Wiwl produces ovate-lanceolate leaflets.

Crcr-normal vs. crinkled leaflets. 


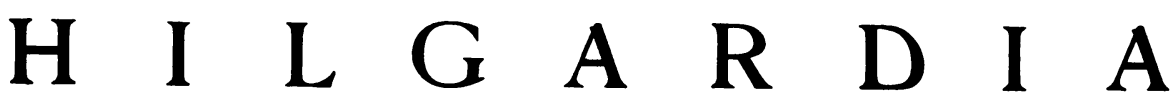

A Journal of Agricultural Science Published by

the California Agricultural Experiment Station

\section{INHERITANCE OF FOUR MORPHOLOGICAL CHARACTERS IN LIMA BEANS ${ }^{1}$}

\section{R. W. ALLARD}

Strains of Lima BEans collected in the wild or obtained in native gardens or market places in tropical or subtropical America, where the species is indigenous, are almost universally characterized by indeterminate growth habit, ovate leaflets, and variegated leaflets (figures 1,2,3). The alternative characters, determinate habit of growth, lanceolate leaflet, and nonvariegated leaflet, respectively, are largely or entirely restricted to cultivated types. These observations thus suggest that the former characters are primitive in the species and that the latter are derived types.

Among the three derived types, only determinate habit has achieved commercial importance. This character is preferred in modern horticultural varieties, although indeterminate or vining habit predominates in varieties grown for their dry edible seed. The mutation from indeterminate to determinate habit apparently occurs only rarely, and it is probable that cultivated determinate varieties are all derived from one or a few ancestors. Primitive determinate types have not been observed. The inheritance of this character difference is mentioned by Mackie and Smith. ${ }^{3}$ They found that a ratio of 3 vine: 1 bush was most frequent in the $\mathrm{F}_{2}$ generation from hybrids, but that other ratios occurring indicated other factors for vininess. No supporting data were given.

The mutation from ovate to lanceolate leaflet also appears to be rare. Primitive strains with this character have not been observed, and there are very few cultivated varieties with lanceolate leaflets. These varieties, called willowleaf types, are of minor importance.

Modern lima bean varieties are about equally divided between variegated and nonvariegated types, even though primitive nonvariegated strains are infrequent. This may indicate that the variegated type possesses less advantage in cultivation than it apparently possesses in nature.

Crinkled leaf is another conspicuous morphological character in lima beans. It differs from the other three characters in that the mutant type is largely or entirely sterile as a result of floral abnormalities which accompany

\footnotetext{
${ }^{1}$ Received for publication June 5, 1953.

${ }^{2}$ Associate Professor of Agronomy, Davis.

${ }^{8}$ Mackie, W. W., and F. L. Smith. Evidence of field hybridization in beans. Jour. Amer. Soc. Agron. $27: 903-09.1935$.
} 


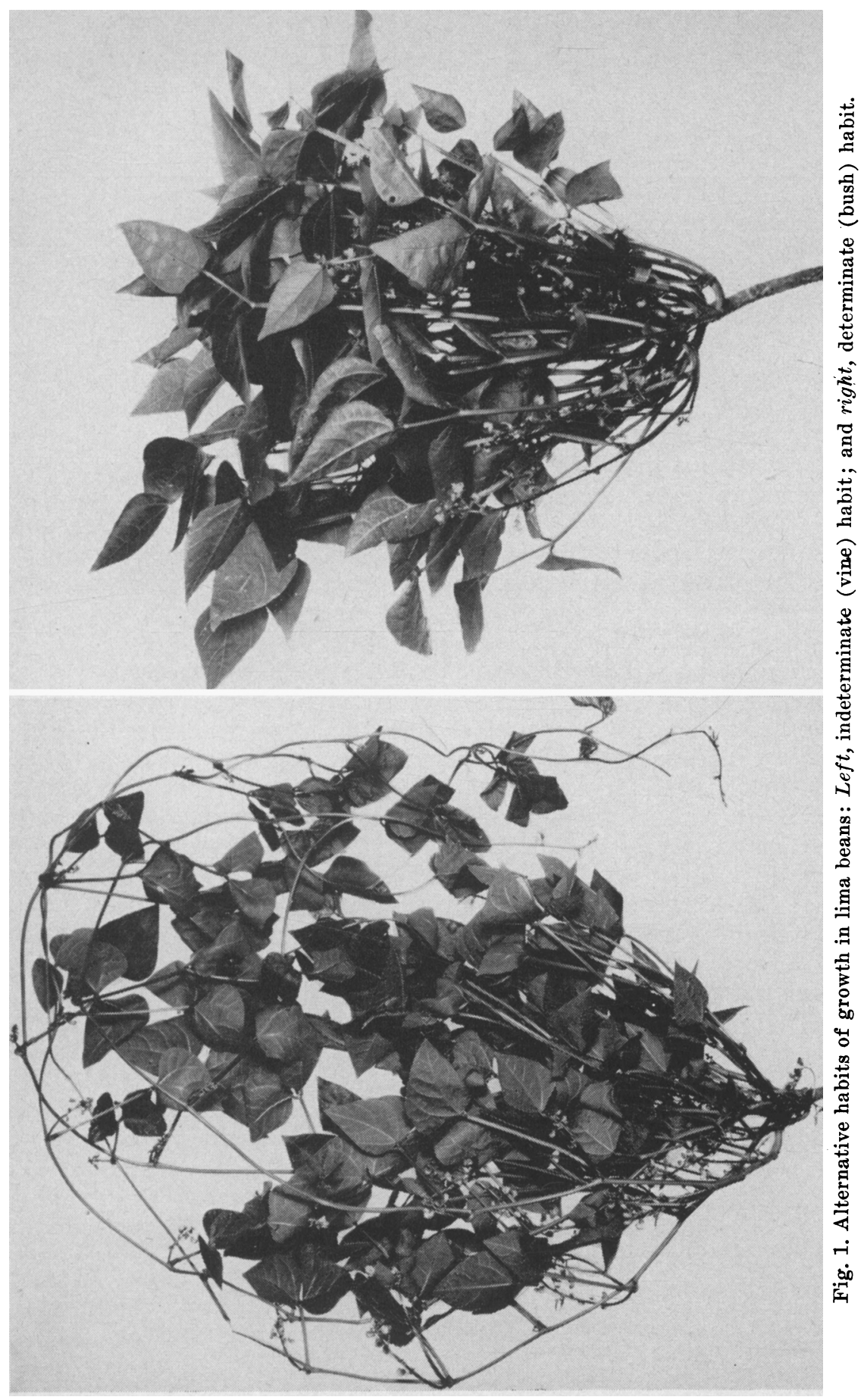


the abnormal leaflets. Despite low survival ability, crinkled-leaf types occur with a frequency of about one per 10,000 in all commercial varieties in which a search has been made for them and with a considerably higher frequency in the progeny of most hybrids. Crinkled leaf is also much more frequent in wild and primitive strains than in cultivated varieties.

Lima beans are frequently cross-pollinated in humid areas and hence are heterozygous; therefore the conspicuously higher frequency of crinkled-leaf types may be related to segregation. It is possible that crinkled-leaf types in highly inbred cultivated varieties arise from recent mutations only, but that the segregation of epistatic suppressor genes allows the expression of cryptic mutants in heterozygous populations, thus increasing their observed frequency. It should be noted that all crinkled-leaf types are not identical phenotypically, suggesting that they are not all governed by the same allele or the same gene. In the present report, a genetic analysis of only the most frequently occurring crinkled-leaf type is presented, together with the Mendelian basis of the inheritance of the other three characters. Because willowleaf, variegated-leaf, and crinkled-leaf characters are expressed in seedlings, they make favorable genetic material. However, they cannot be studied easily in combination in young plants because each character tends to obscure the phenotypic expression of the others.

\section{EXPERIMENTAL RESULTS}

Hybrids of indeterminate $\times$ determinate habit of growth. A total of 25 hybrids between indeterminate and determinate parents was studied during the period 1946 through 1952, largely incidental to plant breeding programs. In each of these 25 hybrids the $\mathrm{F}_{1}$ was indeterminate in habit. The $\mathrm{F}_{2}$ ratios observed in all of the hybrids studied indicate that indeterminate habit is inherited as a monogenic dominant (table 1 ). $\mathrm{F}_{3}$ data from two hybrids support the hypothesis of monogenic control (table 2). However, since Mackie and Smith observed other ratios, the same locus may not have been involved in all of the hybrids studied. Evidence bearing on this possibility is provided by the behavior of crosses of indeterminate $\times$ indeterminate and determinate $x$ determinate. Forty-nine hybrids of the former type studied have produced only indeterminate types in the segregating generations. Similarly, only determinate types have appeared in the progeny of 28 hybrids of the latter type. Included among these hybrids were the appropriate ones to establish that the same locus is concerned in the following varieties or strains of the University of California lima bean accession and introduction series: indeterminate-Wilbur, Westan, Ventura, Hopi 2000, L45, L76, L109, L110, I102; determinate-Henderson, Green-seeded Henderson, Fordhook, Early Market, Evergreen, L59, L106, and G4433. The other parental strains involved in these hybrids represent a wide diversity of germ plasm. Hence, if alleles for determinate habit occur at other loci, their frequency must be low in the species. It is proposed that the symbol Dd be adopted for the gene pair governing this character difference.

Hybrids of variegated $\times$ nonvariegated. $\mathrm{F}_{2}$ or $\mathrm{F}_{2}$ and $\mathrm{F}_{3}$ data are available for nine hybrid combinations of variegated $v s$. nonvariegated parents as shown in tables 3 and 4 . All of the $F_{1}$ hybrids were variegated. The $F_{2}$ and $F_{3}$ 


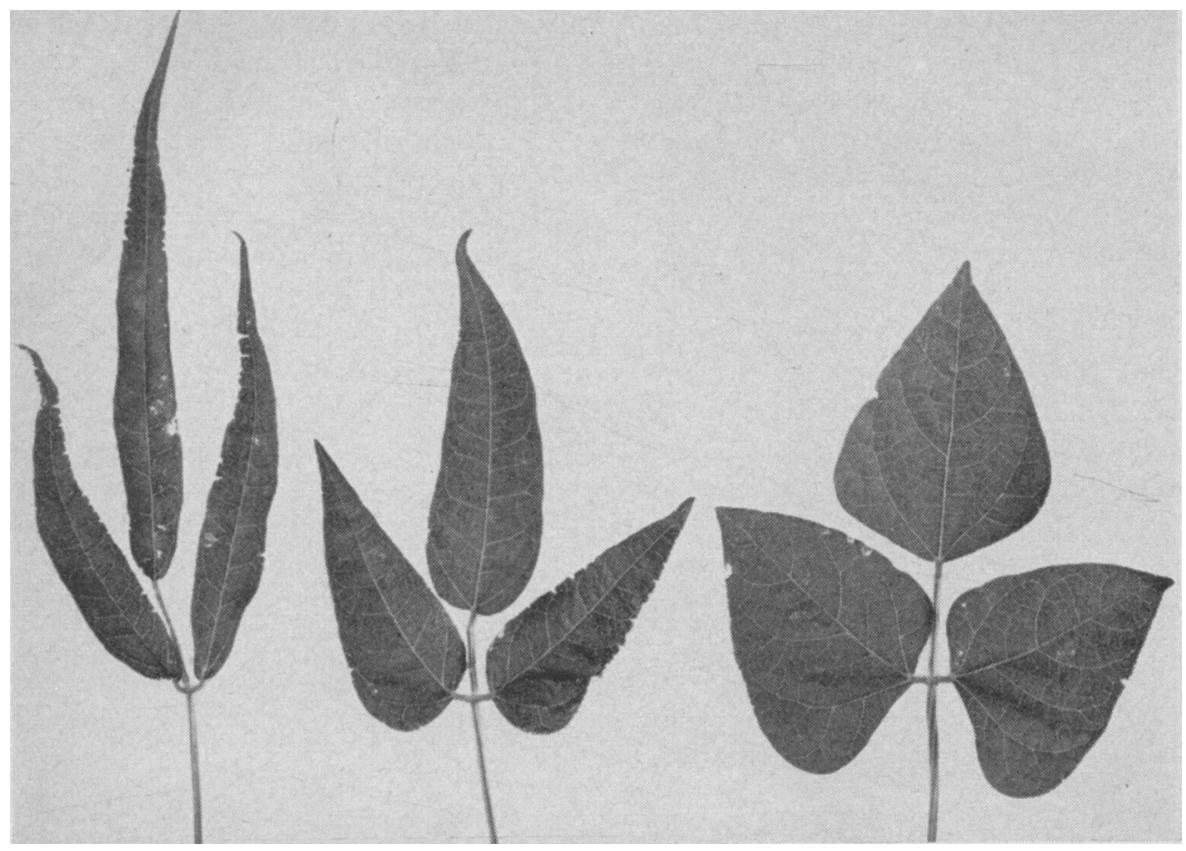

Fig. 2. Leaves of lima bean plants: Left, lanceolate; middle, ovate-lanceolate; and right, ovate.

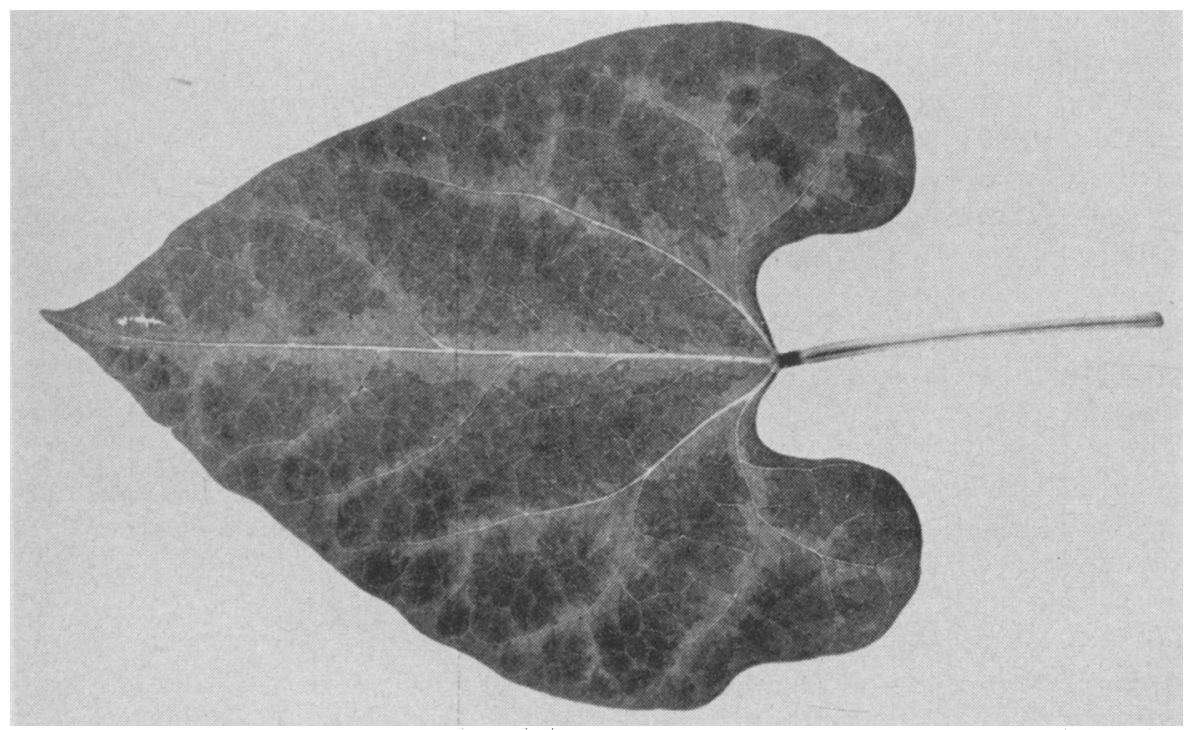

Fig. 3. Lima bean leaflet showing variegated pattern. The alternative nonvariegated phenotype is illustrated in figure 2, right. 
TABLE 1

CLASSIFICATION OF $F_{2}$ PLANTS AND GOODNESS OF FIT TO RATIOS OF 3 INDETERMINATE: 1 DETERMINATE

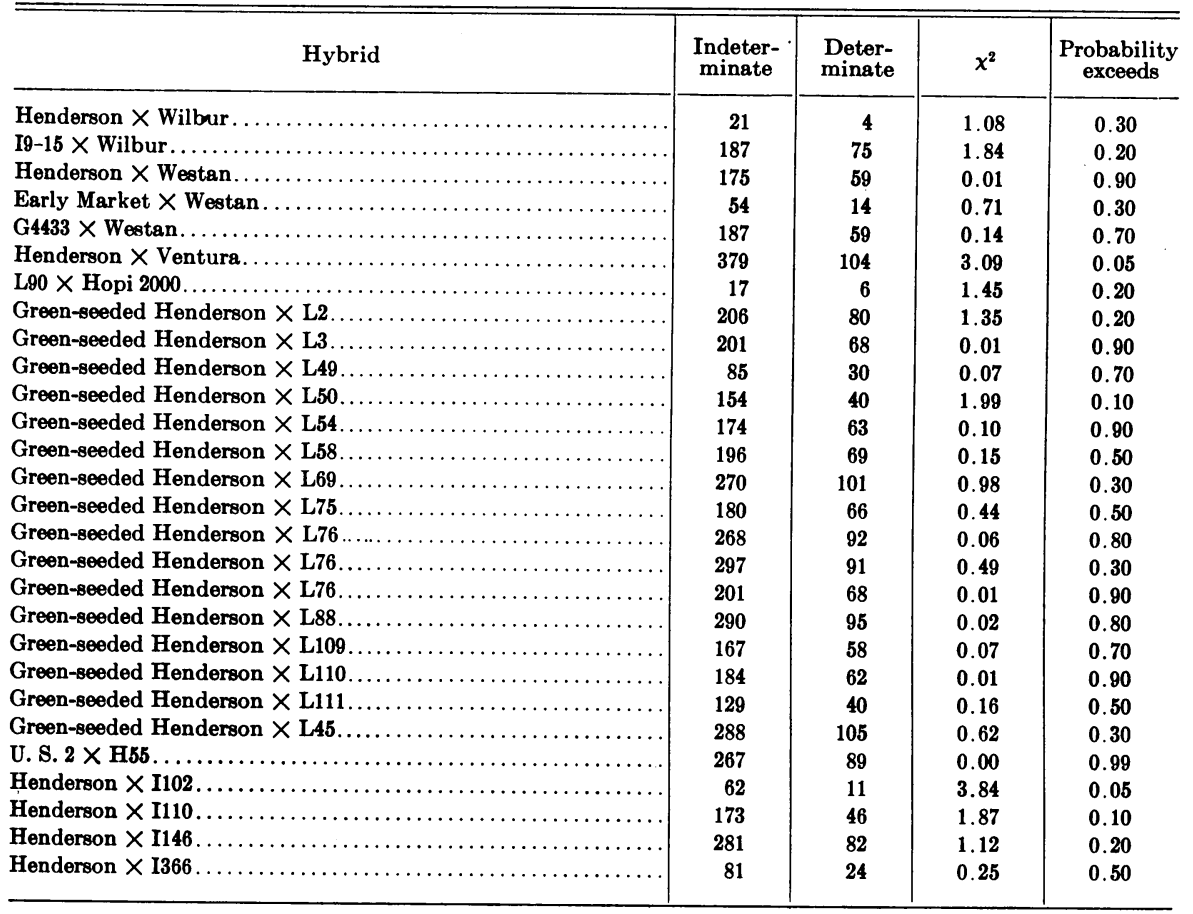

TABLE 2

CLASSIFICATION OF $F_{3}$ PROGENIES FROM INDETERMINATE $F_{2}$ PLANTS AND GOODNESS OF FIT TO A 1:2 RATIO

\begin{tabular}{c|c|c|c|c}
\hline \hline Hybrid & $\begin{array}{c}\text { Homozygous } \\
\text { indeterminate }\end{array}$ & $\begin{array}{c}\text { Segregating } \\
3: 1\end{array}$ & $\chi^{2}$ & $\begin{array}{c}\text { Probability } \\
\text { exceeds }\end{array}$ \\
\hline Green-seeded Henderson $\times$ L2 $\ldots \ldots \ldots \ldots \ldots \ldots \ldots \ldots$ & 27 & 44 & 0.70 & 0.30 \\
Henderson X L109........................... & 26 & 61 & 0.47 & 0.30 \\
\hline
\end{tabular}

ratios observed indicate monogenic control of the character difference, with variegated dominant to nonvariegated. In certain hybrids and particularly under field conditions the expression of the variegation was variable, indicating that environmental conditions as well as the segregation of minor genes influence penetrance. Misclassification of some indistinctly variegated individuals probably accounts for the significant excess of nonvariegated individuals in certain hybrids. The symbol $\mathrm{Vv}$ is proposed for the gene pair controlling this character difference.

Hybrids of ovate $\times$ lanceolate. Three different hybrid combinations of this type were studied (table 5). One of the lanceolate parents, L110, was ob- 
TABLE 3

CLASSIFICATION OF $F_{2}$ PLANTS AND GOODNESS OF FIT TO RATIOS OF 3 VARIEGATED:1 NONVARIEGATED

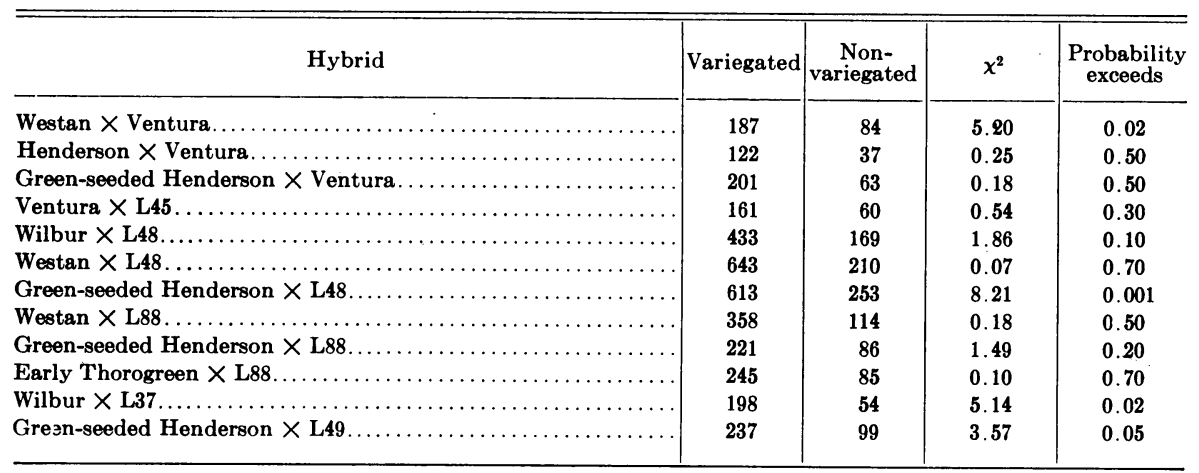

\section{TABLE 4}

CLASSIFICATION OF $\mathrm{F}_{3}$ PROGENIES OF SINGLE $\mathrm{F}_{2}$ PLANTS AND GOODNESS OF FIT TO A RATIO OF 1 HOMOZYGOUS VARIEGATED:2 SEGREGATING:1 HOMOZYGOUS NONVARIEGATED

\begin{tabular}{|c|c|c|c|c|c|}
\hline Hybrid & $\begin{array}{c}\text { Homozygous } \\
\text { variegated }\end{array}$ & $\begin{array}{c}\text { Segregating } \\
3: 1\end{array}$ & $\begin{array}{c}\text { Homozygous } \\
\text { non- } \\
\text { variegated }\end{array}$ & $\chi^{2}$ & $\begin{array}{c}\text { Probability } \\
\text { exceeds }\end{array}$ \\
\hline $\begin{array}{l}\text { Wilbur } \times \text { L37 } \ldots \ldots \ldots \ldots \ldots \ldots \ldots \\
\text { Green-seeded Henderson } \times \text { L2 } \ldots \\
\text { Wilbur } \times \text { L } 48 \ldots \ldots \ldots \ldots \ldots \ldots \ldots \ldots\end{array}$ & $\begin{array}{l}81 \\
10 \\
31\end{array}$ & $\begin{array}{r}142 \\
31 \\
86\end{array}$ & $\begin{array}{l}57 \\
14 \\
35\end{array}$ & $\begin{array}{l}4.17 \\
1.47 \\
2.84\end{array}$ & $\begin{array}{l}0.10 \\
0.30 \\
0.20\end{array}$ \\
\hline
\end{tabular}

TABLE 5

CLASSIFICATION OF $F_{2}$ PLANTS AND GOODNESS OF FIT TO A RATIO OF 1 LANCEOLATE:2 OVATE-LANCEOLATE: 1 OVATE LEAFLET

\begin{tabular}{|c|c|c|c|c|c|}
\hline Hybrid & WIWl & Wlwl & wlwl & $x^{2}$ & $\begin{array}{l}\text { Probability } \\
\text { exceeds }\end{array}$ \\
\hline 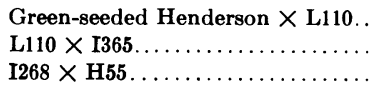 & $\begin{array}{l}60 \\
44 \\
84\end{array}$ & $\begin{array}{r}119 \\
81 \\
164\end{array}$ & $\begin{array}{l}67 \\
40 \\
93\end{array}$ & $\begin{array}{l}0.659 \\
0.248 \\
0.970\end{array}$ & $\begin{array}{l}0.70 \\
0.80 \\
0.50\end{array}$ \\
\hline
\end{tabular}

tained from the Woodruff Seed Company and the other, I268, was obtained from Dr. Roy Magruder of the U. S. Department of Agriculture. In all three hybrids the $\mathrm{F}_{1}$ was intermediate between the parents in shape of leaflets (fig. 2). In the $\mathrm{F}_{2}$ generation ovate, ovate-lanceolate, and lanceolate types occurred in a ratio of 1:2:1 (table 5). The distinction between types was clear cut and no difficulties were encountered in classification. Ovate and lanceolate $\mathrm{F}_{2}$ individuals invariably bred true in the $\mathrm{F}_{3}$ generation, while ovatelanceolate individuals repeated the $\mathrm{F}_{2}$ segregation in $\mathrm{F}_{3}$. These character 
differences are obviously governed by a single gene pair with slight dominance in the direction of lanceolate. The hybrid between the two lanceolate parents has not been studied; hence it is not known whether they carry the same or different alleles for lanceolate leaflets. The symbol Wlwl is suggested for the gene pair.

Normal $\times$ crinkled leaf. The particular crinkled-leaf mutant studied was discovered in an $\mathrm{F}_{4}$ progeny line of the hybrid Wilbur $\times$ L76. A typical leaf

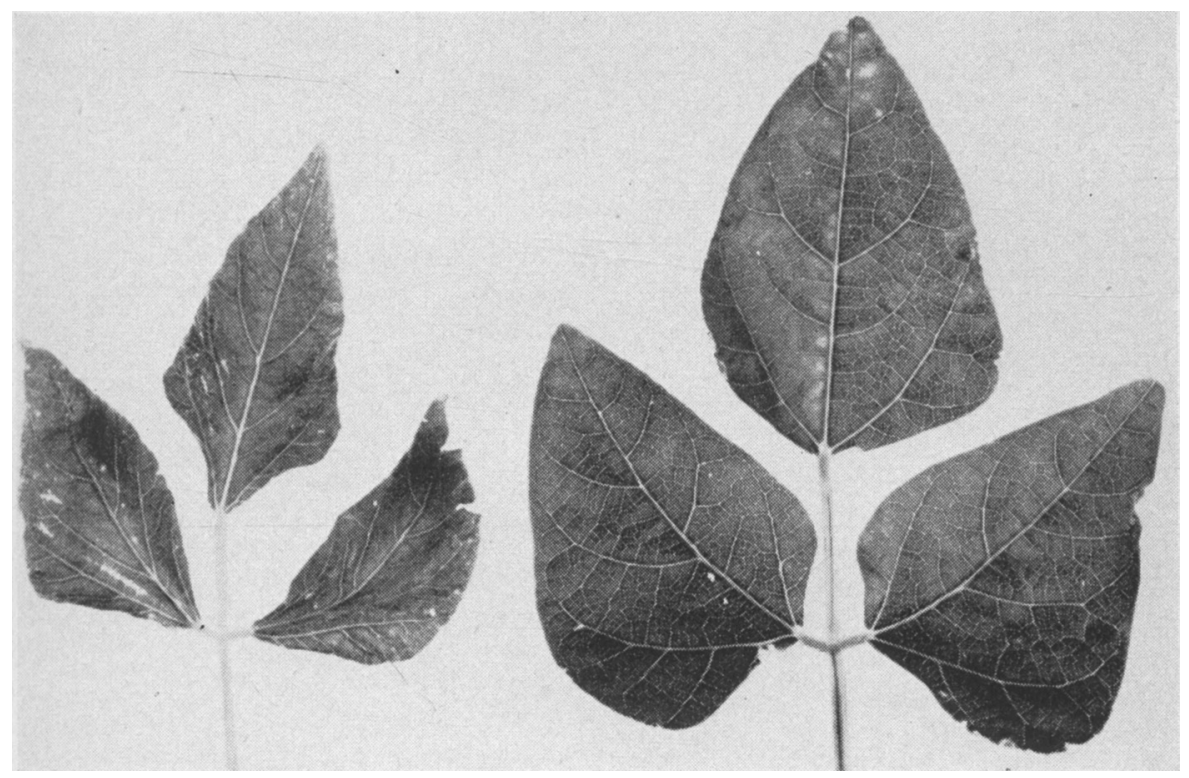

Fig. 4. Lima bean leaves: Left, normal; and right, crinkled.

is shown in figure 4 . This mutant is also characterized by failure of a majority of the flowers to develop beyond the bud stage with the result that it is nearly completely sterile. Occasional normal flowers are formed, however, making it possible to obtain hybrids with the mutant type. $\mathrm{F}_{1}$ hybrids with the variety Wilbur had normal leaves and flowers and were apparently completely fertile. In the $\mathrm{F}_{2}$ generation, 300 normal and 81 crinkled-leaf individuals were observed, a satisfactory fit to a 3:1 ratio. Because crinkled-leaf plants were nearly or completely sterile, progeny tests with them were not possible. However, among $30 \mathrm{~F}_{3}$ progenies derived from normal $\mathrm{F}_{2}$ plants, 18 segregated approximately 3 normal: 1 crinkled, and 12 were homozygous for normal leaves. This is an acceptable fit to the 2:1 ratio expected if the character is controlled by a monogenic dominant. The deficiency in the recessive class in $F_{2}$ and similar deficiencies in segregating $F_{3}$ progenies may indicate lower viability of the mutant type. The symbol Crer is suggested for this gene pair. 

The journal Hilgardia is published at irregular intervals, in volumes of about 600 pages. The number of issues per volume varies.

Subscriptions are not sold. The periodical is sent as published only to libraries, or to institutions in foreign countries having publications to offer in exchange.

You may obtain a single copy of any issue free, as long as the supply lasts; please request by volume and issue number from:

\section{Publications Office \\ College of Agriculture \\ Berkeley 4, California}

The limit to nonresidents of California is 10 separate issues on a single order. A list of the issues still available will be sent on request. 